\title{
PENGARUH KESADARAN MEREK TERHADAP NIAT BELI DENGAN SIKAP REKOMENDASI SPONSOR SEBAGAI VARIABEL MEDIASI PADA KONSUMEN SAMSUNG DI KOTA BANDA ACEH
}

\author{
ISKANDARSYAH MADJID ${ }^{1}$ DAN ADEK MAULANA ${ }^{2}$ \\ ${ }^{1}$ Dosen pada Fakultas Ekonomi, Universitas Syiah Kuala, Banda Aceh \\ ${ }^{2}$ Alumni Fakultas Ekonomi, Universitas Syiah Kuala, Banda Aceh
}

The purpose of this study was to measure the impact of brand awreness to purchase intention with attitude toward sponsor recomendation as mediating variables on Phone cell consumers in Banda Aceh. Data we collected from a sample of 100 respondents. Data collection equipments used in this research is a questionnaire. The sampling technique used was purposive sampling. Hierarchical Linear Modeling (HLM) was used as method of analysis to determine the effect of all the variables involved. Based on the result of HLM analysis there is a positive effect on brand awareness toward purchase inten, brand awareness has a positive influence on the sponsor recommendation behavior, sponsor recommendation behavior has a poitive influence on purchase intentions, and attitude toward sponsor recomendation mediated the effect of the brand awareness toward purchase intention.

Keywords: Brand Awareness, Attitude Toward Sponsor Recomendation, Purchase Intention, Hierarchical Linear Modelling 


\section{PENDAHULUAN}

Komunikasi merupakan hal yang biasa terjadi dalam kehidupan sehari-hari manusia dan menjadi hal yang sangat penting bagi kehidupan masyarakat sehari-hari. Kebutuhan untuk saling berkomunikasi dengan sesama dan mendapatkan informasi dengan cepat menjadi sangat tinggi. Pertumbuhan teknologi yang cepat membuat masyarakat mau tak mau harus mengikutinya. Salah satu alat komunikasi yang berkembang dengan cepat adalah ponsel. Pada tahun 1993, Samsung Mobile Phone merilis seri SH-700, yang lebih membanggakan lagi desain nya dirancang dengan ukuran yang lebih kecil dan lebih ramping serta kualitas suara yang lebih baik. Dengan produk yang lebih baik dan kampanye pemasaran yang lebih agresif, Samsung berhasil mengambil setengah pangsa pasar ponsel di Korea dari Motorola. Namun pada tahun 1997 hampir semua bisnis di Korea menyusut dan tidak terkecuali juga pada Samsung. Mereka menjual bisnisnya untuk meringankan utang dan mengurangi karyawan menjadi 50.000. Namun berkat industri elektronik mereka ,akhirnya bisa berhasil untuk terus tumbuh hingga sekarang. Samsung pertama kali masuk ke pasar Smartphone dunia pada tahun 2001, pada saat itu Samsung menciptakan sebuah ponsel dengan teknologi layar sentuh yaitu Samsung SPH I300 yang dirilis di Amerika Serikat. Hadir dengan berbasis Sistem Operasi Palm, dengan tampilan yang sangat sederhana. Persaingan perusahaan Samsung dengan Apple pada saat itu dapat dibilang sangat ketat namun Apple memang masih jauh lebih unggul ketimbang Samsung. Penerus dari Samsung S bahkan menuai hasil yang lebih manis, produk Galaxy S II berhasil terjual puluhan juta unit dan sampai saat ini produk ini masih diminati oleh banyak orang. Samsung membanjiri pasar dengan banyaknya pilihan dari segmen lowend, midend, maupun high-end. Hal ini terbukti dengan pengiriman ponsel dari berbagai vendor yang setiap tahunnya meningkat, termasuk Samsung, yang dirangkum oleh International Data Corporation (IDC) seperti terlihat pada Tabel 1.

Samsung memang berhasil menguasai pasar Smartphone berkat beberapa ponsel andalannya. Namun dalam setahun terakhir justru pangsa pasar
Tabel 1

Top 5 WW Smartphone Vendors, 2015Q2 Unit Shipments (Millions)

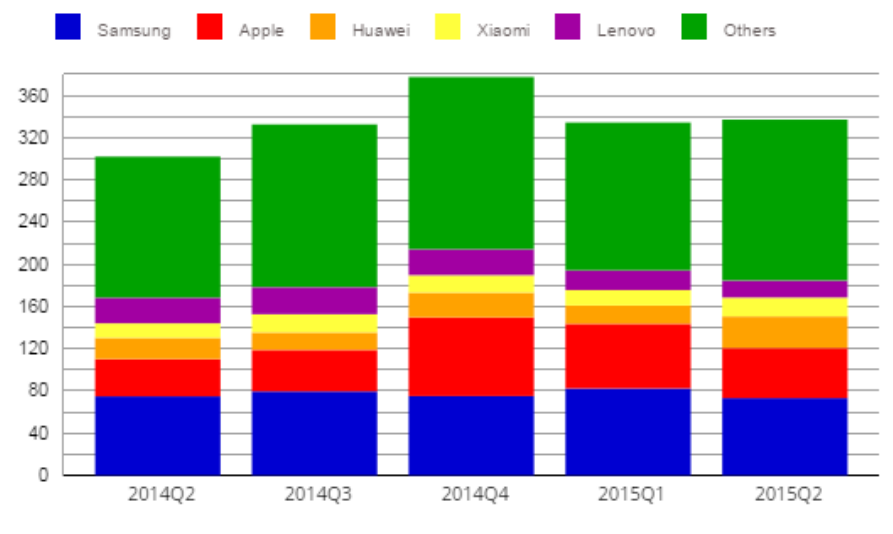

Samsung mengalami kecenderungan menurun dibanding para pesaingnya. Bahkan produk dari tiongkok, Xiaomi, mengalami pertumbuhan yang sangat pesat dari pangsa pasar $4,6 \%$ pada kuartal 2 tahun 2014 melonjak menjadi 5,3\% pada kuartal 2 tahun 2015. Persaingan Smartphone saat ini tidak hanya berfokus pada Samsung yang pada awal kemunculan sistem operasi Android sangat menguasai pasar, banyak merek lain saat ini mulai bermunculan dengan mengandalkan smartphone dengan spesifikasi tinggi dan harga lebih terjangkau tetapi kualitasnya tidak kalah dengan Samsung. Hal ini menjadi salah satu penyebab pangsa pasar Samsung terus berkurang. Kemudian Samsung berusaha kembali menaikkan pangsa pasarnya dengan mensponsori berbagai bidang, dengan tujuan untuk menaikkan pangsa pasarnya dengan promosi yang gencar. Dengan banyaknya Samsung mensponsori berbagai hal, sehingga menimbulkan niat beli di benak konsumen.

Bagi konsumen, merek merupakan sebuah nilai tambah bagi mereka. dimana keyakinan dan kepercayaan mereka terhadap merek tersebut membuat mereka rela membayar lebih karena persepsi mereka terhadap merek tersebut. merek merupakan janji atas sebuah kualitas yang membentuk hubungan antara perusahaan dan konsumen Maka dari itu banyak dari konsumen yang mau membayar lebih kepada suatu merek karena adanya jaminan kualitas yang diberikan dalam produk yang produsen tawarkan. Untuk menciptakan merek yang baik, maka perusahaan harus mampu membangun sebuah brand equity (ekui- 
tas merek). Brand equity (ekuitas merek) merupakan nilai tambah yang diberikan pada produk dan jasa, nilai ini bisa dicerminkan dalam cara konsumen berfikir, merasa dan bertindak terhadap merek, harga, pangsa pasar, dan profitabilitas yang dimiliki perusahaan. suatu merek memiliki ekuitas merek yang tinggi atau rendah dapat diindikasikan berdasarkan kesadaran merek (brand awareness), asosiasi merek (brand association), persepsi kualitas (perceived quality), loyalitas merek (brand loyalty). Kesadaran merek mempengaruhi persepsi dan tingkah laku, sehingga kesadaran merek dapat di katakan sebagai key of brand asset atau kunci pembuka untuk masuk ke elemen lainnya (Aaker dan McLoughlin, 2010). Dengan kata lain, seperti apa yang dinyatakan Simamora (2003), kesadarn merek merupakan komponen penyusun ekuitas merek yang penting. Selain itu, dapat dikatakn pula bahwa pembentukan awareness adalah tahap awal dalam mengkomunikasikan brand suatu produk.

Rumusan masalah dalam penelitian ini adalah bagaimana kesadaran merek berpengaruh terhadap niat beli pada konsumen ponsel samsung di kota Banda Aceh.

Tujuan dari penelitian ini adalah untuk menguji pengaruh kesadaran merek terhadap niat beli pada konsumen ponsel samsung di kota Banda Aceh. Penelitian ini juga bisa menjadi bahan masukan bagi produsen perusahaan yang ingin meningkatkan kesadaran merek di benak konsumen.

\section{KESADARAN MEREK}

Kesadaran merek (Brand awareness) adalah kesanggupan seseorang pembeli untuk mengenali, mengingat kembali suatu merek sebagai sutatu kategori produk tertentu (Durianto, 2001)

Hasil penelitian ini menunjukkan bahawa hubungan signifikan pengaruh kesadaran merek terhadap niat beli yang di mediasikan oleh sikap rekomendasi sponsor. Kerangka penelitian dapat di lihat pada Gambar 1.

\section{Pengaruh Kesadaran Merek Terhadap Niat Beli}

Kesadaran merek (Brand awareness) adalah kesanggupan seseorang pembeli untuk mengenali, mengingat kembali suatu merek sebagai sutatu kategori produk tertentu (Durianto, 2001)

Hubungan positif antara kesadaran merek terhadap niat beli dipengaruhi oleh seorang konsumen, sejauh mana dia mengetahui produk, semakin dia mengenal suatu produk maka semakin tinggi niat beli seorang konsumen terhadap barang tersebut. Hasil penelitian ini menunjukkan bahwa: H1 : Kesadaran merek berpengaruh terhadap niat beli pada konsumen ponsel samsung

\section{Pengaruh Kesadaran Merek \\ Terhadap Sikap Rekomendasi Sponsor}

Bahwa dua tujuan penting dari sponsorship olahraga dan seni adalah untuk meningkatkan brand awareness dan untuk membangun, memperkuat dan mengubah brand image. Sejak awal penggunaanya sebagai alat promosi, yaitu pada tahun 1970an, dimana sponsorship hanya dilirik sebagai kesempatan beriklan dan keramahtamahan perusahaan, sekarang ini sponsorship telah berkembang implementasinya. Semakin berkembang zaman sponsorhip banyak di lakukan pada suatu event yang dianggap dapat menarik atensi yang tinggi. Hasil penelitian ini menunjukkan bahwa:

H2 : Kesadaran merek berpengaruh terhadap sikap rekomendasi sponsor pada konsumen ponsel samsung.

\section{Pengaruh Sikap Rekomendasi Sponsor Terhadap Niat Beli}

Tsiotsou (2008) mendapatkan hasil bahwa sponsorship berpengaruh positif pada minat pembelian konsumen yang dimana menunjukkan niat yang lebih tinggi untuk membeli dan merekomendasikan produk sponsor. Cornwell dan Cotte (2005) menghasilkan temuan bahwa kegiatan sponsorship menciptakan efek positif dalam niat

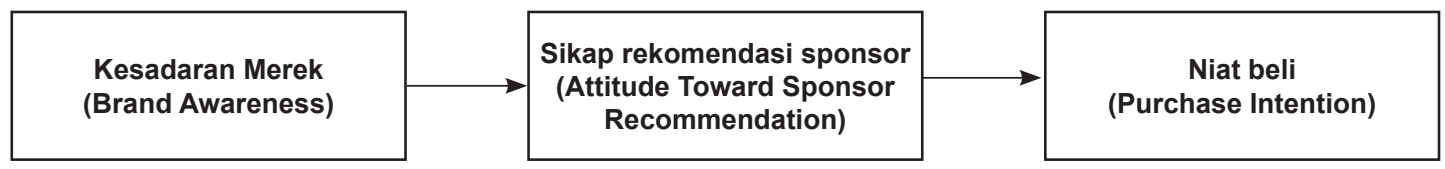

Gambar 1. Kerangka Penelitian 
pembelian konsumen.

Eagleman dan Krohn (2012) menghasilkan temuan bahwa pelaksanaan sponsorship mampu membuat konsumen bersikap lebih positif dan menunjukkan niat yang lebih besar untuk membeli produk sponsor. Hasil penelitian ini menunjukkan bahwa:

H3 : Sikap rekomensi sponsor berpengaruh terhadap niat beli konsumen ponsel samsung.

\section{Pengaruh Kesadaran Merek Terhadap Niat Beli Dengan Sikap Rekomendasi Sebagai Vari- abel Mediasi}

Rowley dan Willams (2008) bahwa dua tujuan penting dari sponsorship olahraga dan seni untuk meningkatkan brand awareness dan untuk membangun,memperkuat dan mengubah brand image. Menurut Masterman (2007), sejak awal penggunaannya sebagai alat promosi, yaitu pada tahun 1970an, dimana sponsorhip hanya dilirik sebagai kesempatan beriklan dan keramahtamahan perusahaan, sekarang ini sponsorhip telah berkembang implementasinya. Semakin berkembang zaman, sponsorship banyak yang dilakukan pada suatu event yang di anggap dapat menarik atensi yang tinggi. Hasil penelitian ini menunjukkan bahwa:

H4 : Kesadaran merek berpengaruh terhadap niat beli dengan sikap rekomendasi sponsor sebagai variabel mediasi pada konsumen ponsel samsung.

\section{METODELOGI PENELITIAN}

Lokasi penelitian ini adalah konsumen ponsel samsung yang berada di Kota Banda Aceh. Populasi dalam penelitian ini adalah konsumen pengguna ponsel samsung yang berada di Kota Banda Aceh. Sedangkan teknik sampel yang di gunakan adalah Purposive sampling dengan jumlah responden dalam penelitian ini adalah 100 orang (jumlah minimal dalam penelitian menggunakan alat analisa diskriminan) (Hair et al., 2010). Metode analisi yang di gunakan adalah Hierarchical Linear Modelling

Dalam kuesioner responden diminta untuk menyatakan tingkat persetujuan mengikuti skala pengukuran yang digunakan dalam penelitian ini yaitu dengan menggunakan skala likert. Jawaban yang mendukung pertanyaan diberi skor yang tinggi (5) sedangkan untuk jawaban yang tidak atau kurang mendukung diberi skor rendah (1). (Sugiyono, 2012).

\section{Variabel Bebas}

Variabel bebas atau independent variabel penelitian ini adalah kesadaran merek dimana kesadaran merek ini diukur dengan 4 item pertanyaan untuk menguji seberapa baik kesadaran merek berpengaruh terhadap niat beli dan sikap rekomendasi sponsor.

Sebuah instrument dikatakan valid apabila dapat mengungkapkan data dari variabel yang diteliti secara tepat dan mempunyai validitas tinggi, tinggi rendahnya validitas instrument menunjukkan sejauh mana data yang terkumpul tidak menyimpang dari gambaran tentang variabel yang dimaksud (Sekaran, 2006). Seluruh pertanyaan dinyatakan valid jika memiliki tingkat significansi alpha dibawah 5\%.

Hasil uji validitas dan reliabilitas terhadap penelitian ini dapat kita lihat pada tabel berikut ini. Tabel 1 menunjukkan bahwa data hasil penelitian ini adalah valid dan reliabel. Dinyatakan reliabel karena nilai cronbach's alpha dari masing masing variabel lebih besar daripada 0,6

\section{Uji Statistik}

Di dalam penelitian ini terdapat variabel intervening (mediasi) yaitu Sponsor yang di rekomendasi. Menurut Barron dan Kenny (1986) suatu variabel disebut variabel intervening jika variabel tersebut ikut mempengaruhi hubungan antara prediktor (independen) dan variabel kriteria (dependen).

Untuk mengetahui pengaruh kesadaran merek terhadap niat beli para pengguna ponsel di Banda Aceh maka penulis menggunakan alat ukur Hierarchical Linier Model (HLM) . Model linier hirarki memungkinkan untuk penelitian secara simultan hubungan di seluruh level. Dua model yang di kembangkan agar mencpai hal ini: salah satu yang mencerminkan hubungan dalam unit level rendah, dan yang ke dua bagaimana hubungan model dalam unit level yang lebih rendah bervari- 
Tabel 1

\begin{tabular}{|l|c|c|c|c|}
\hline \multicolumn{1}{|c|}{ Variabel } & $\begin{array}{c}\text { Item } \\
\text { Pertanyaan }\end{array}$ & $\begin{array}{c}\text { Nilai } \\
\text { r hitung }\end{array}$ & $\begin{array}{c}\text { Nilai } \\
\text { r tabel }\end{array}$ & $\begin{array}{c}\text { Cronchbach's } \\
\text { Alpha }\end{array}$ \\
\hline Kesadaran Merek (X) & KM1 & 0,006 & 0,007 & \\
& KM2 & 0,883 & 0,645 & 0,670 \\
& KM3 & 0,733 & 0,413 & \\
& KM4 & 0,715 & 0,411 & \\
\hline Niat Beli (Y) & NB1 & 0,714 & 0,452 & \\
& NB2 & 0,461 & 0,243 & \\
& NB3 & 0,699 & 0,424 & \\
& NB4 & 0,812 & 0,538 & \\
& NB5 & 0,219 & 0,107 & \\
\hline Sikap Rekomendasi Sponsor & SR1 & 0,506 & 0,247 & \\
& SR2 & 0,095 & 0,033 & \\
& SR3 & 0,823 & 0,499 & \\
& SR4 & 0,892 & 0,630 & \\
\hline
\end{tabular}

Tabel 2

Uji F

Pengaruh simulata Kesadaran Merek terhadap Niat Beli dengan Sikap Rekomendasi Sponsor sebagai variabel mediasi

\begin{tabular}{|ll|r|r|r|r|r|}
\hline Model & & \multicolumn{1}{c|}{$\begin{array}{c}\text { Sum of } \\
\text { Squares }\end{array}$} & \multicolumn{1}{c|}{ df } & Mean Square & \multicolumn{1}{c|}{$\mathrm{F}$} & \multicolumn{1}{c|}{ Sig. } \\
\hline 1 & Regression & 7,218 & 1 & 7,218 & 25,693 &, $000^{\mathrm{b}}$ \\
& Residual & 27,532 & 98 &, 281 & & \\
& Total & 34,750 & 99 & & & \\
\hline 2 & Regression & 14,028 & 2 & 7,014 & 32,831 &, $000^{\circ}$ \\
& Residual & 20,722 & 97 &, 214 & & \\
& Total & 34,750 & 99 & & & \\
\hline
\end{tabular}

a. Dependent Variable: $Y$

b. Predictors: (Constant), $X$

c. Predictors: (Constant), X, Z

Sumber: Data Primer diolah (2016)

asi Antara unit.

Oleh karenanya peralatan analisis data yang digunakan dalam penelitian ini untuk mengetahui pengaruh kesadaran merek terhadap niat beli dengan sikap rekomendasi sponsor sebagai variabel mediasi, digunakan persamaan sebagai berikut:

$$
\begin{gathered}
Y=\alpha+\beta X \\
Z=\alpha+\beta X \\
Y=\alpha+\beta X+\beta Z
\end{gathered}
$$

Dimana:

$\mathrm{X}=$ Kesadaran Merek

$\mathrm{Y}=$ Niat Beli

$\mathrm{Z}=$ Sikap Rekomendasi Sponsor

\section{HASIL DAN PEMBAHASAN}

Hasil penelitian dari 100 konsumen pengguna ponsel samsung yang memberikan respon terhadap kuesioner yang diberikan. Terdapat 55 responden sebagai pelajar/mahasiswa, 8 responden sebagai guru/dosen, 5 responden sebagai PNS, 27 responden sebagai pegawai swasta, dan 5 responden lagi sebagai pengusaha atau lain-lain.

\section{Hasil Uji Secara Simultan}

Pada Tabel 2 terlihat bahwa uji pengaruh secara simultan (uji F) pengaruh kesadaran merek terhadap niat beli sebelum melalui proses mediasi adalah 25,693 dengan nilai signifikan $<5 \%(0,000)$ 
Sedangkan setelah melaui proses mediasi melalui variabel sikap rekomendasi sponsor nilai $\mathrm{F}$ tabelnya menjadi 32,831. Dengan demikian dapat disimpulkan bahwa kesdaran merek berpengaruh signifikan terhadap niat beli, baik sebelum melaui proses mediasi, maupun setelah proses mediasi melalui variabel sikap rekomendasi sponsor.

\section{Hasil Uji Secara Parsial}

Pembuktian hipotesis yang di ajukan dalam penelitian ini akan dilakukan dari hasil uji parsial dengan menggunakan uji t. Uji t ini digunakan untuk membuktikan pengaruh yang signifikan antara variabel independen terhadap variabel dependen, dimana apabila nilai t tabek menunjukkan di terimanya hipotesis yang di ajukan. Nilai t hitung

\section{Pengaruh Kesadaran Merek terhadap Niat Beli}

Berdasarkan Tabel 3 dapat kita lihat bahwa nilai $\mathrm{T}_{\text {hitung }}$ variabel independen kesadaran merek terhadap variabel dependen niat beli adalah 5,069 denagan tingkat signifikansi 0,000. Dapat disum- pulkan bahwa kesdaran merek berpengaruh signifikan terhadap niat beli.

Dapat dilihat pada hasil regresi dan nilai $\mathrm{T}_{\text {tabel }}$ didapat melalui sig. $\alpha=0,05$.

Hasil analisi regresi untuk mengetahui pengaruh secara parsial antara kesadaran merek terhadap niat beli dengan sikap rekomendasi sponsor sebagai variabel mediasi dapat dilihat pada Tabel 4 .

\section{Pengaruh Kesadaran Merek terhadap Sikap Rekomendasi Sponsor}

Berdasarkan Tabel 4 dapat dilihat bahwa nilai $\mathrm{T}_{\text {hitung }}$ variabel independen kesadaran merek terhadap variabel intervening sikap rekomendasi sponsor adalah 2,647 dengan tingkat signifikansi 0,000. Dapat disimpulkan bahwa kesadaran merek memiliki pengaruh signifikan terhadap sikap rekomendasi sponsor.

\section{Pengaruh Sikap Rekomendasi Sponsor terhadap Niat beli}

Berdasarkan Tabel 2 dapat kita lihat bahwa nilai $\mathrm{T}_{\text {hitung }}$ untuk variabel sikap rekomendasi

Tabel 3

Uji Parsial (Uji t)

Kesadaran Merek Terhadap Sikap Rekomendasi Sponsor

Dampaknya pada Niat Beli

\begin{tabular}{|c|c|c|c|c|c|c|}
\hline \multirow{2}{*}{\multicolumn{2}{|c|}{ Model }} & \multicolumn{2}{|c|}{ Unstandardized Coefficients } & \multirow{2}{*}{$\begin{array}{c}\begin{array}{c}\text { Standardized } \\
\text { Coefficients }\end{array} \\
\text { Beta }\end{array}$} & \multirow[b]{2}{*}{$t$} & \multirow[b]{2}{*}{ Sig. } \\
\hline & & $\mathrm{B}$ & Std. Error & & & \\
\hline \multirow[t]{2}{*}{1} & (Constant) & 2,244 &, 354 & & 6,347 &, 000 \\
\hline & $x$ & 440 &, 087 & 456 & 5,069 &, 000 \\
\hline \multirow[t]{3}{*}{2} & (Constant) & 1,003 & ,379 & & 2,647 &, 009 \\
\hline & $x$ & 179 &, 089 & , 185 & 2,015 &, 047 \\
\hline & Z &, 562 & 100 & 519 & 5,646 &, 000 \\
\hline
\end{tabular}

a. Dependent Variable: $Y$

Sumber: Data Primier diolah (2016)

Tabel 4

Uji t

Pengaruh Kesadaran Merek terhadap Sikap Rekomendasi Sponsor

\begin{tabular}{|c|c|c|c|c|c|c|}
\hline \multirow{2}{*}{\multicolumn{2}{|c|}{ Model }} & \multicolumn{2}{|c|}{ Unstandardized Coefficients } & \multirow{2}{*}{$\begin{array}{c}\begin{array}{c}\text { Standardized } \\
\text { Coefficients }\end{array} \\
\text { Beta } \\
\end{array}$} & \multirow[b]{2}{*}{$\mathrm{t}$} & \multirow[b]{2}{*}{ Sig. } \\
\hline & & $B$ & Std. Error & & & \\
\hline & (Constant) & 2,210 &, 313 & & 7,060 &, 000 \\
\hline & $x$ &, 465 &, 077 &, 522 & 6,052 &, 000 \\
\hline
\end{tabular}

a. Dependent Variable: $Z$ 
sponsor terhadap niat beli adalah 5,646 dengan signifikansi 0,000. Dapat disimpulkan sikap rekomendasi sponsor berpengaruh secara signifikan terhadap niat beli.

\section{Pengaruh Kesadaran Merek terhadap Niat Beli melalui Mediasi Sikap \\ Rekomendasi Sponsor}

Berdasarkan Tabel 2 dapat kita lihat bahwa nilai $\mathrm{T}_{\text {hitung }}$ pengaruh kesadaran merek terhadap niat beli melalui mediasi sikap rekomendasi sponsor adalah 2,015 dengan singkat signifikansi 0,047. Dapat disimpulakan bahwa setelah proses mediasi melalui sikap rekomendasi sponsor, kesadaran merek berpengaruh signifikan terhadap niat beli.

\section{KESIMPULAN}

Hipotesis yang di perkirakan yaitu:

1. Kesadaran Merek berpengaruh terhadap Niat beli pada konsumen ponsel samsung di kota Banda Aceh (Ha1).

2. Kesadaran merek berpengaruh terhadap sikap rekomendasi sponsor pada konsumen ponsel di Kota Banda Aceh (Ha2).

3. Sikap rekomendasi sponsor berpengaruh terhadap niat beli pada konsumen ponsel samsung di kota Banda Aceh (Ha3).

4. Kesaradan merek berpengaruh terhadap niat beli melalui sikap rekomendasi sponsor konsumen ponsel samsung di kota Banda Aceh (Ha4). 


\section{REFERENSI}

Aaker, D.A. dan McLoughin,D (2010). Strategic Market Management - Global Marketing. Journal of world business.

Cornwell, Bettina T and Coote Leonard V. 2005.Corporate Sponsorship of a cause: the role of identification in purchase intent.Journal of Business Research 58 268- 276

M.Baron Reuben and David A.kenny. 1986. The Moderator-Mediator Variable Distinction in Social Psychological Research: Conceptual, Strategic, and Statistical Considerations. Journal of personalityand social psychology.

Durianto,Darmadi et al.2001. Brand Equity Ten Strategi Memimpin Pasar. Jakarta. PT Gramedia pustaka utama

Eagleman, Andrea N. and Krohn Brian D. 2012.Sponsorship Awareness, Attitudes, and Purchase Intentions of Road Race Series Participants.Sport Marketing Quarterly, 21, 210-220

Hair, j., Black, W., Babin, B., Anderson, R. (2010). Multivariate data analysis (7th ed.). Uppersaddle River, N.J.: Pearson Prentice Hall.

Sekaran, Uma. 2003. Research Methods For Business. New Jersey: John Willey \& Sons Inc.

Simmamora, Bilson, 2003, Membongkar Kotak Hitam Konsumen, Jakarta: PT. Gramedia Pustaka Utama

Sugiyono, 2012, Metode Penelitian Bisnis. Bandung: Alfabeta

Tsitsou, Rodoula. 2009. Delineating the outcomes of Sponsorship Sponsor image, word of mouth, and purchase intentions. International Journal of Retail \& Distribution Management 37 (4), pp: 358-369 